\title{
Impacts of Pharmacy Intervention on Appropriateness of Antibiotics Use in Pneumonia Patients
}

\author{
Azizah Nasution $^{1 *(\mathbb{D})}$, Khairunnisa Khairunnisa ${ }^{1}$, Syed Azhar Syed Sulaiman ${ }^{2}$ \\ ${ }^{1}$ Department of Pharmacology, Faculty of Pharmacy, Universitas Sumatera Utara, Medan, Indonesia; ${ }^{2}$ Department of Clinical \\ Pharmacy, School of Pharmaceutical Sciences, Universiti Sains Malaysia, George Town, Malaysia
}

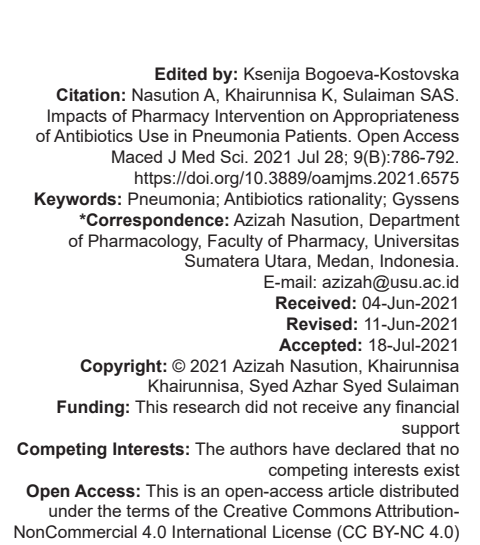

\section{Introduction}

Pneumonia remains as a major health threat, especially in developing countries. Globally, the disease infects about 450 million people per year. It contributes to $7 \%$ of the total global deaths every year [1]. In Indonesia year 2010, pneumonia was included into the top ten diseases with high hospital admission with the proportion of cases of $53.95 \%$ for male and $46.05 \%$ for female with crude fatality rate of $7.6 \%$. Based on 2018 Riskesdas data, the national prevalence of pneumonia in Indonesia by healthcare workers increased to $2.0 \%$ from $1.8 \%$ in 2013 . The prevalence of pneumonia in the Province of Sumatera Utara has increased from 1.1\% in 2013 to $2.3 \%$ in 2018 [2].

Pneumonia is an infection of the pulmonary parenchyma caused by various pathogens such as bacteria, fungi, viruses, and parasites that cause inflammation in the lung tissue [3]. The bacterial pneumonia is usually caused by infection of Streptococcus pneumoniae. Other possible infecting bacteria in pneumonia comprise Chlamydia pneumonia, Mycoplasma pneumoniae, Chlamydia psittaci, and Legionella pneumophila. These bacteria are known as "atypical" because pneumonia caused by these organisms might have slightly different symptoms, appear different on a chest X-ray, or respond to different antibiotics than the typical bacteria that cause pneumonia [4]. Critically ill patients admitted to intensive care unit frequently suffer from bacterial pneumonia transmitted through mechanical ventilation [5]. A multicenter study found that most (80.9\%) of the patients with community-acquired pneumonia (CAP) were infected with influenza [6]. Other study conducted on 515 children aged younger than 5 years with acute lower respiratory infections also confirmed that $78.1 \%$ of them experienced viral infection [7].

The main complications associated with pneumonia are bacteremia, pleural effusion, and lung abscess. The severity of pneumonia varies and is associated with many determinants including the infecting bacteria as well as age and the patients' clinical conditions. In addition, pneumonia also tends to be more serious in people with heart disease, diabetes mellitus, and chronic obstructive disease [8].

Due to these complicated conditions experienced by the pneumonia patients, they have to receive multiple drug therapy and may result in drug-related 
problems. One of the unwanted problems is irrational/ inappropriate provision of antibiotics which can further directly cause bacterial resistance. The high incidence of pneumonia requires high provision of antibiotics [9]. Thus, inappropriate use of antibiotics remains as a serious global health challenge. A study found that the appropriate level of antibiotic use without pharmacy intervention was only $55 \%$ which improved to $74 \%$ with pharmacy interventions [10]. A study indicated that $30-80 \%$ of antibiotic provision were not based on accurate indication, which can further increase bacterial resistance, treatment costs, morbidity, and mortality [11], [12]. Many other pharmacy intervention studies on the usage of wide range of antibiotics and varied purposes in the treatment of pneumonia patients have been undertaken elsewhere [10], [13], [14], [15]. Furthermore, efforts to avoid inappropriate use of antibiotics in all areas of the world are important to maximize clinical outcomes, minimize side effects, avoid toxicity, reduce treatment costs, and most importantly to reduce the global emergence of bacterial resistance [16].

In light of these problems, this study aimed to analyze the impact of pharmacy intervention on the appropriateness of antibiotics provision in the treatment of inpatients with pneumonia admitted to Universitas Sumatera Utara (USU) hospital, Medan, Indonesia.

\section{Methods}

This cohort study compared the appropriateness of antibiotic provision between group of pneumonia patients without pharmacy intervention (usual care) and those with intervention admitted to USU Hospital, Medan Indonesia, periods of 2018 and July up to September 2019. The inclusion criteria were pneumonia patients age $\geq 18$ years old, received antibiotics, did not suffer from human immunodeficiency virus and tuberculosis. A self-designed questionnaire was developed to assessed the required data including age of the patients, gender, medical and medication histories, antibiotics utilization, organ functions, white blood cell level, and other related data. Ethical clearance of this study (No 1868/VI/SP/2019) was obtained from the Health Research Ethical Committee, School of Nursing, USU, Indonesia. Inform consent was filled out by each of the patients in the intervention group before conducting the study. The primary concern in determining the number of samples is that the samples should be represent the population. A study indicated that appropriate levels of antibiotic use in group with and without interventions were $74 \%$ and $55 \%$, respectively [6]. The minimum required sample size of each group, using electronic sample size calculator for the cohort study, was 67 at confidence level (1- $\alpha)$ of $95 \%$, with $80 \%$ power (1- $\beta$ as type II error), proportion of appropriate levels of drugs resolved without and with pharmacy intervention are 0.55 and 0.65 as a guess value (middle value of $55 \%$ and $74 \%$ ), respectively, of the cohort study [17]. Baseline data were recruited from the patients' medical records year $2018(n=33)$, while, the prospective data were recruited from 3-month patients' admission year 2019 ( $n=42)$ with the involvement of pharmacy intervention. The important findings regarding appropriateness of antibiotics use obtained by pharmacists in the group without intervention were distributed and explained to other healthcare providers during intervention period. Characteristics of the patients and antibiotics utilization in groups with usual care and intervention were descriptively analyzed. The appropriateness of antibiotics use in both groups was analyzed considering the medical conditions (comorbidities and organs' function) and medication histories of the patients as well as local culture and sensitivity tests (CST). The results were classified using the Gyssens method and categorized into proper and improper (dose, intervals, routes, too long provision, too short provision, less effective, and more costly) and other trustable literatures [18], [19], [20]. The significant difference between groups with and without interventions in terms of inappropriate provision of antibiotics was analyzed applying unpaired t-test ( $p$ $<0.05$ was considered significant). All analyses were performed using the program of SPSS version 17.

\section{Results}

The minimum sample size required for each group was 67. For the usual care, there were 132 patients admitted to the hospital during 2018, of which only 33 patients met the inclusion criteria. Thus, only these patients could be used as sample in the group without intervention. Only 42 pneumonia patients met the inclusion criteria for the intervention group during 3-month period admission year 2019. Therefore, these patients were used as group with intervention.

\section{Characteristics of the patients}

Characteristics of the patients with pneumonia with and without interventions can be seen in Table 1. In group without intervention, $51.5 \%$ of the patients were male and $48.5 \%$ of them were female. As much as $61.9 \%$ were male and $38.1 \%$ were female in the intervention group. Statistical analysis indicated that there was no significant difference between male and female in both groups. Numerically, pneumonia was more prevalent in male compared to female. 
Table 1: Characteristics of the pneumonia patients with and without interventions

\begin{tabular}{|c|c|c|c|c|c|}
\hline \multirow[t]{2}{*}{ Characteristics } & \multicolumn{2}{|c|}{ Without intervention } & \multicolumn{2}{|l|}{ Intervention } & \multirow[t]{2}{*}{$\mathrm{p}$} \\
\hline & $n=33$ & $(\%)$ & $n=42$ & $(\%)$ & \\
\hline \multicolumn{6}{|l|}{ Gender } \\
\hline Male & 17 & 51.5 & 26 & 61.9 & \\
\hline Female & 16 & 48.5 & 16 & 38.9 & \\
\hline $\mathrm{p}$ & 0.862 & & 0.123 & & \\
\hline \multicolumn{6}{|l|}{ Age (years) } \\
\hline $18-27$ & 0 & 0 & 1 & 2.38 & \\
\hline $28-36$ & 1 & 3.03 & 3 & 7.14 & \\
\hline $37-46$ & 6 & 18.2 & 4 & 9.52 & \\
\hline $47-55$ & 4 & 12.1 & 2 & 4.76 & \\
\hline $56-65$ & 7 & 21.2 & 15 & 35.71 & \\
\hline$>65$ & 15 & 45.5 & 17 & 40.48 & \\
\hline Mean age (years) & $60.52 \pm 15.48$ & & $60.48 \pm 14.76$ & & 0.991 \\
\hline \multicolumn{6}{|c|}{ Number of patients with LOS: } \\
\hline$<7$ days & 24 & 72.22 & 29 & 61.90 & \\
\hline$>7$ days & 10 & 27.28 & 13 & 38.10 & \\
\hline Mean LOS (days) & $6.78 \pm 2.43$ & & $6.54 \pm 3.29$ & & 0.727 \\
\hline
\end{tabular}

The mean ages in group with and without interventions were $60.48 \pm 14.76$ years and 60.52 \pm 15.48 years, respectively. There was no significant difference in terms of age between group with and without interventions, $p=0.991$. Most $(45.5 \%)$ of the pneumonia patients in the group without intervention were above 65 years old. The same result was also found that most $(40.48 \%)$ of the patients in the group with the intervention were at the age of above 65 years.

As demonstrated in Table 1, most of the pneumonia patients with and without interventions were hospitalized in less than 7 days. Mean length of stay (LOS) of the pneumonia patients in groups with and without interventions were $6.54 \pm 3.29$ days and $6.78 \pm 2.43$ days, respectively. There was no significant difference in terms of LOS between groups with and without interventions, $p=0.727$.

\section{Antibiotics utilization during hospitalization}

The antibiotics provided to the pneumonia patients are shown in Figure 1. The number of units of each antibiotic provided to group without intervention in decreasing order was ceftriaxone, meropenem, ciprofloxacin, gentamycin, azithromycin, moxifloxacin, levofloxacin, and metronidazole. The most widely provided antibiotic in group without intervention was ceftriaxone (276 units provided to 24 patients) with average of 11.5 units during their hospitalization (mean LOS of $6.78 \pm 2.43$ days) and the least frequently provided antibiotic was metronidazole. The provision of antibiotics in group with intervention in decreasing order was ceftriaxone, meropenem, ciprofloxacin, gentamycin, azithromycin, levofloxacin, metronidazole, vancomycin, and cefixime. The most widely provided antibiotics in group with intervention was also ceftriaxone (397 units provided to 36 pneumonia patients) with average about 11.0 units during their hospitalization (mean LOS of $6.54 \pm 3.29$ days) and the least frequently provided antibiotic was cefixime given only to one patient.
The study found that $23(69.70 \%)$ of the patients without intervention received monotherapy and only $10(30.30 \%)$ of them received combination therapy. In the intervention group, $17(40.48 \%)$ of the patients received monotherapy and $25(59.52 \%)$ of them received combination therapy.

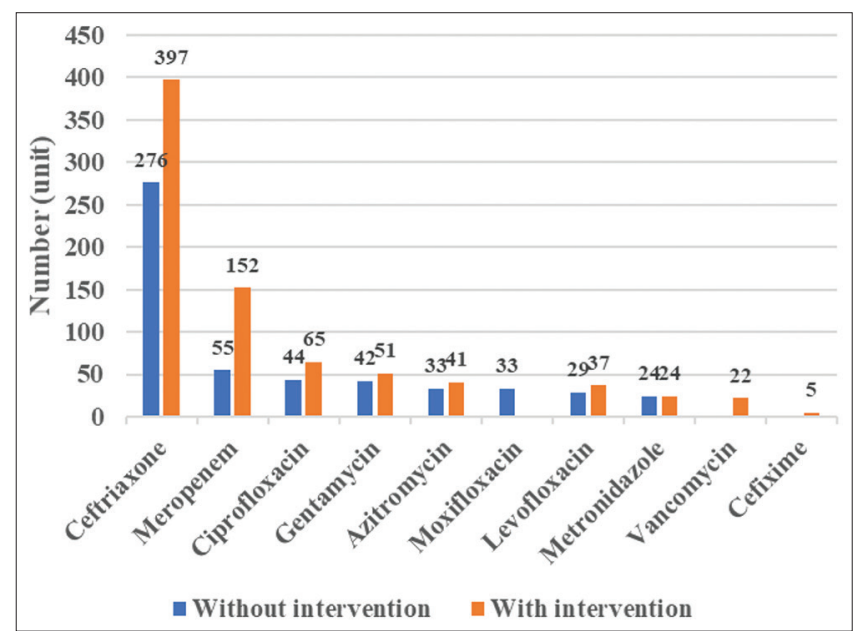

Figure 1: Antibiotics utilization in pneumonia patients with and without interventions

\section{Appropriateness of antibiotic provision}

The results of the detailed analysis of the inappropriate selection of antibiotics provided to the pneumonia patients with and without interventions including reasons for inappropriateness and consequences as well as recommendations are listed in Tables 2 and 3, respectively. In this study, only seven out of 13 categories of Gyssens were detected in the treatment of patients with pneumonia. These categories comprised appropriate use of antibiotics, inappropriate dose, inappropriate dosing interval, too long duration of treatment, too short duration of treatment, the use of not effective antibiotics, and the use of toxic and expensive antibiotics.

As shown in Table 2, as many as 22 incidences of inappropriate use of antibiotics were experienced by $16(48.49 \%)$ of the 33 patients in group without intervention. This means that one patient could experience more than one incidence. The occurrences of inappropriate use of antibiotics in this group in decreasing order were the use of more expensive antibiotics (moxifloxacin) provided to six patients, followed by the use of less effective antibiotics (levofloxacin, ciprofloxacin, and ceftriaxone) evidenced from CST tests given to five patients, the inappropriate dose of levofloxacin received by four patients who were also had chronic kidney disease (CKD), too short duration of antibiotics treatment provided to four patients, too long duration of antibiotics treatment provided to two patients, and inappropriate dosing interval of antibiotics provided to one patient. 
Table 2: Description of inappropriate antibiotics provision in group without intervention

\begin{tabular}{|c|c|c|c|c|}
\hline Category & $\begin{array}{l}\text { Provided } \\
\text { Antibiotics }\end{array}$ & $\begin{array}{l}\text { Number of } \\
\text { cases }\end{array}$ & $\begin{array}{l}\text { Reasons for } \\
\text { inappropriateness/ } \\
\text { consequence }\end{array}$ & Recommendation \\
\hline $\begin{array}{l}\text { There are } \\
\text { other cheaper } \\
\text { antibiotics }\end{array}$ & Moxifloxacin & 6 & $\begin{array}{l}\text { Levofloxacin } \\
\text { demonstrated } \\
\text { good inhibitory } \\
\text { effect to the } \\
\text { infecting bacteria } \\
\text { and cheaper }\end{array}$ & $\begin{array}{l}\text { Levofloxacin should be } \\
\text { the drug of choice for } \\
\text { the patients }\end{array}$ \\
\hline \multirow[t]{5}{*}{$\begin{array}{l}\text { There are other } \\
\text { more effective } \\
\text { antibiotics } \\
\text { (bacterial } \\
\text { resistance } \\
\text { occurred) }\end{array}$} & $\begin{array}{l}\text { Levofloxacin; } \\
\text { continue } \\
\text { provided }\end{array}$ & 1 & $\begin{array}{l}\text { The patient was } \\
\text { infected with } \\
\text { Micrococcus } \\
\text { species and } \\
\text { Streptococcus } \\
\text { alfa hemolyticus. } \\
\text { CST proved } \\
\text { that the bacteria } \\
\text { were resistant to } \\
\text { levofloxacin }\end{array}$ & $\begin{array}{l}\text { Vancomycin showed } \\
\text { good inhibition activity. } \\
\text { Thus, this should be } \\
\text { the drug of choice for } \\
\text { the patient }\end{array}$ \\
\hline & $\begin{array}{l}\text { Levofloxacin; } \\
\text { continue } \\
\text { provided }\end{array}$ & 1 & $\begin{array}{l}\text { This patient was } \\
\text { infected with } \\
\text { Acinetobacter } \\
\text { baumannii (ESBL) } \\
\text { carbapenemase } \\
\text { also resistant } \\
\text { levofloxacin }\end{array}$ & $\begin{array}{l}\text { Amikacin demonstrated } \\
\text { good inhibition activity. } \\
\text { It should be the drug of } \\
\text { choice for the patient }\end{array}$ \\
\hline & $\begin{array}{l}\text { Ciprofloxacin; } \\
\text { continue } \\
\text { provided }\end{array}$ & 1 & $\begin{array}{l}\text { The patient was } \\
\text { infected with } \\
\text { Micrococcus } \\
\text { species resistant to } \\
\text { ciprofloxacin }\end{array}$ & $\begin{array}{l}\text { CST indicated that the } \\
\text { bacteria was sensitive } \\
\text { to levofloxacin, thus } \\
\text { this should be chosen } \\
\text { for the patient }\end{array}$ \\
\hline & $\begin{array}{l}\text { Levofloxacin; } \\
\text { continue } \\
\text { provided }\end{array}$ & 1 & $\begin{array}{l}\text { The patient was } \\
\text { infected with } \\
\text { Staphylococcus } \\
\text { epidermidis } \\
\text { coagulase- } \\
\text { negative resistant } \\
\text { to levofloxacin }\end{array}$ & $\begin{array}{l}\text { The bacteria } \\
\text { was sensitive to } \\
\text { meropenem. This } \\
\text { antibiotic should be } \\
\text { provided }\end{array}$ \\
\hline & $\begin{array}{l}\text { Ceftriaxone; } \\
\text { continue } \\
\text { provided }\end{array}$ & 1 & $\begin{array}{l}\text { The patient was } \\
\text { infected with } \\
\text { Pseudomonas } \\
\text { aeruginosa } \\
\text { carbapenemase } \\
\text { resistant to } \\
\text { ceftriaxone }\end{array}$ & $\begin{array}{l}\text { The pathogen } \\
\text { was sensitive } \\
\text { to levofloxacin. } \\
\text { Ceftriaxone should } \\
\text { be replaced with } \\
\text { levofloxacin }\end{array}$ \\
\hline $\begin{array}{l}\text { Inappropriate } \\
\text { use }\end{array}$ & $\begin{array}{l}\text { Levofloxacin } \\
500 \mathrm{mg} / \text { day }\end{array}$ & 4 & $\begin{array}{l}\text { Too high dose. } \\
\text { Two patients } \\
\text { were diagnosed } \\
\text { as CKD Stage } 3 \text {, } \\
\text { one patient Stage } \\
4 \text {, one patient } \\
\text { Stage 5. Due to } \\
\text { decrease in kidney } \\
\text { function }\end{array}$ & $\begin{array}{l}\text { These patients should } \\
\text { receive loading } \\
\text { dose } 500 \mathrm{mg} \text {, then } \\
\text { maintenance dose } 250 \\
\text { mg/day }\end{array}$ \\
\hline \multirow[t]{4}{*}{$\begin{array}{l}\text { Too short } \\
\text { provision }\end{array}$} & $\begin{array}{l}\text { Levofloxacin } \\
750 \mathrm{mg} / \text { day } \\
\text { for } 3 \text { days }\end{array}$ & 1 & $\begin{array}{l}\text { Too short } \\
\text { provision may } \\
\text { cause bacterial } \\
\text { resistance }\end{array}$ & $\begin{array}{l}\text { Provision of } \\
\text { levofloxacin } 750 \mathrm{mg} / \\
\text { day for } 7-14 \text { days }\end{array}$ \\
\hline & $\begin{array}{l}\text { Ceftriaxone } 1 \\
\text { g/ } 12 \mathrm{~h} \text { for } 2 \\
\text { days }\end{array}$ & 1 & Same as above & $1 \mathrm{~g} / 12 \mathrm{~h}$ for $4-14$ days \\
\hline & $\begin{array}{l}\text { Moxifloxacin } \\
400 \mathrm{mg} / \text { day } \\
1 \text { for } 5 \text { days } \\
\text { Moxifloxacin } \\
400 \mathrm{mg} / \text { day } \\
\text { for } 4 \text { days }\end{array}$ & 1 & Same as above & $\begin{array}{l}400 \mathrm{mg} / \text { day for } 7-14 \\
\text { days }\end{array}$ \\
\hline & $\begin{array}{l}\text { Azithromycin } \\
500 \mathrm{mg} / \text { day } \\
\text { for } 6 \text { days } \\
\text { Azithromycin } \\
500 \mathrm{mg} / \mathrm{day} \\
\text { for } 7 \text { days }\end{array}$ & 1 & $\begin{array}{l}\text { Excessive } \\
\text { provision of } \\
\text { azithromycin }\end{array}$ & $\begin{array}{l}\text { Azithromycin should be } \\
\text { provided } 500 \mathrm{mg} / \mathrm{day} \\
\text { for } 3 \text { days or } 500 \mathrm{mg} \\
\text { once, then } 250 \mathrm{mg} / \mathrm{day} \\
\text { for } 4 \text { days }\end{array}$ \\
\hline $\begin{array}{l}\text { Inappropriate } \\
\text { dosing interval }\end{array}$ & $\begin{array}{l}\text { Cefadroxil } \\
500 \mathrm{mg} / 12 \mathrm{~h}\end{array}$ & 1 & $\begin{array}{l}\text { Too high dose. } \\
\text { The patient also } \\
\text { suffered from CKD }\end{array}$ & $\begin{array}{l}\text { Interval should be } \\
\text { increased to } 500 \\
\mathrm{mg} / 24 \mathrm{~h}\end{array}$ \\
\hline Total & & 22 & & \\
\hline
\end{tabular}

However, in the group with intervention, as listed in Table 3, only 14 incidences of inappropriate use of antibiotics experienced by 14 (33.33\%) of the 42 patients. The incidences (in decreasing order) comprised the use of less effective antibiotics provided to six patients, inappropriate dose of antibiotics received by four pneumonia patients with CKD, inappropriate dosing intervals of meropenem provided to three patients, and too short provision of ceftriaxone received by one patient.

Table 3: Description of inappropriate antibiotics use in group with intervention

\begin{tabular}{|c|c|c|c|c|}
\hline Category & Provided & $\begin{array}{l}\text { No of } \\
\text { cases }\end{array}$ & $\begin{array}{l}\text { Reasons for } \\
\text { inappropriateness/ } \\
\text { consequence }\end{array}$ & Recommendation \\
\hline \multirow{6}{*}{$\begin{array}{l}\text { There are } \\
\text { other more } \\
\text { effective } \\
\text { antibiotics }\end{array}$} & Meropenem & 1 & $\begin{array}{l}\text { Meropenem less effective } \\
\text { than vancomycin }\end{array}$ & Vancomycin \\
\hline & Ceftriaxone & 1 & $\begin{array}{l}\text { Ceftriaxone less effective } \\
\text { than meropenem }\end{array}$ & Meropenem \\
\hline & Levofloxacin & 1 & $\begin{array}{l}\text { Levofloxacin less } \\
\text { effective than vancomycin }\end{array}$ & Vancomycin \\
\hline & Ceftriaxone & 1 & $\begin{array}{l}\text { Ceftriaxone less effective } \\
\text { than vancomycin }\end{array}$ & Vancomycin \\
\hline & Ceftriaxone & 1 & $\begin{array}{l}\text { Ceftriaxone less effective } \\
\text { than vancomycin }\end{array}$ & Vancomycin \\
\hline & Ceftriaxone & 1 & $\begin{array}{l}\text { Ceftriaxone less effective } \\
\text { than levofloxacin }\end{array}$ & Levofloxacin \\
\hline \multirow[t]{4}{*}{$\begin{array}{l}\text { Inappropriate } \\
\text { dose of } \\
\text { antibiotics }\end{array}$} & $\begin{array}{l}\text { Gentamycin } \\
240 \mathrm{mg} / \text { day }\end{array}$ & 1 & $\begin{array}{l}\text { Patient had CKD; the } \\
\text { provided dose was too } \\
\text { high }\end{array}$ & $\begin{array}{l}\text { Dose of gentamycin } \\
\text { should be reduced to } \\
106 \mathrm{mg} / \text { day }\end{array}$ \\
\hline & $\begin{array}{l}\text { Levofloxacin } \\
500 \mathrm{mg} / 24 \mathrm{~h}\end{array}$ & 1 & $\begin{array}{l}\text { Patient was on CKD } \\
\text { Stage } 5 \text {, dose of } \\
\text { levofloxacin was too high }\end{array}$ & $\begin{array}{l}\text { Loading dose, } 500 \mathrm{mg} \text {; } \\
\text { maintenance dose, } \\
250 \text { mg once daily }\end{array}$ \\
\hline & $\begin{array}{l}\text { Meropenem } 1 \\
\mathrm{~g} / 12 \mathrm{~h}\end{array}$ & 1 & $0.25-0.5 \mathrm{~g} / 24 \mathrm{~h}$ & \\
\hline & $\begin{array}{l}\text { Levofloxacin } \\
500 \mathrm{mg} / 24 \mathrm{~h}\end{array}$ & 1 & $\begin{array}{l}\text { CKD patient with } \mathrm{ClCr} \\
5.13 \mathrm{ml} / \mathrm{min}\end{array}$ & $\begin{array}{l}500 \mathrm{mg} \text { initially, then } \\
250 \mathrm{mg} \text { once daily }\end{array}$ \\
\hline $\begin{array}{l}\text { Inappropriate } \\
\text { dosing }\end{array}$ & $\begin{array}{l}\text { Meropenem } 1 \\
\mathrm{~g} / 8 \mathrm{~h}\end{array}$ & 1 & $\begin{array}{l}\text { CKD patient }(\mathrm{ClCr} 33.28 \\
\mathrm{ml} / \mathrm{min})\end{array}$ & $1 \mathrm{~g} / 12$ hours \\
\hline \multirow[t]{2}{*}{ interval } & $\begin{array}{l}\text { Meropenem } 1 \\
\mathrm{~g} / 12 \mathrm{~h}\end{array}$ & 1 & Haemodialysis patient & $0.25-0.5 \mathrm{~g} / 24 \mathrm{~h}$ \\
\hline & $\begin{array}{l}\text { Meropenem } 1 \\
\mathrm{~g} / 12 \mathrm{~h}\end{array}$ & 1 & $\begin{array}{l}\text { CKD patient with } \mathrm{ClCr} \\
7.72 \mathrm{ml} / \mathrm{min}\end{array}$ & $0.25-0.5 \mathrm{~g} / 24 \mathrm{~h}$ \\
\hline $\begin{array}{l}\text { Too short } \\
\text { provision }\end{array}$ & $\begin{array}{l}\text { Ceftriaxone } \\
1 \mathrm{~g} / 12 \mathrm{~h} \text { for } 3 \\
\text { days }\end{array}$ & 1 & $\begin{array}{l}\text { Too short provision } \\
\text { may cause bacterial } \\
\text { resistance }\end{array}$ & $1 \mathrm{~g} / 12 \mathrm{~h}$ for $4-14$ days \\
\hline Total & & 14 & & \\
\hline
\end{tabular}

Results of the inappropriateness of antibiotics provided to pneumonia patients with and without interventions grouped by Gyssens category described in Tables 2 and 3 are summarized in Table 4.

Table 4: Summary of Inappropriate antibiotics provided to pneumonia patients without intervention $(n=33)$ and with intervention $(n=42)$ based on Gyssens category

\begin{tabular}{llll}
\hline Category & \multicolumn{2}{l}{ Number of incidences } & $\mathrm{p}$ \\
\cline { 2 - 3 } & without Intervention & Intervention & \\
\hline There are other cheaper antibiotics & 6 & 0 & 0.043 \\
There are other more effective antibiotics & 5 & 6 & \\
Inappropriate dose & 4 & 4 & \\
Too short provision & 4 & 1 & \\
Too long provision & 2 & 0 & \\
Inappropriate dosing interval & 1 & 3 \\
Total incidence & 22 & 14 \\
Incidence per patient & $22 / 33=0.66$ & $14 / 42=0.33$ \\
\hline
\end{tabular}

As shown in Table 4, incidences of inappropriate use of antibiotics per patients decreased from 0.66 in group without intervention to 0.33 in group with pharmacy interventions. Overall, un-pared t-test conducted in this study proved that inappropriate use of antibiotics decreased significantly in group with pharmacy intervention ( $n=42)$ compared to those in group without intervention $(n=33), p=0.043$. The study proved that pharmacy intervention plays an important role to reduce the inappropriate use of antibiotics in the treatment of patients with pneumonia. 


\section{Discussion}

In this study, the incidence of pneumonia was not significant different between male and female. However, according to Henig, pneumonia was more common in male due to their habit of smoking in which it is the main independent risk factor for the occurrence of pneumonia in adults [21]. Patients with older age seemed to be more prone to have pneumonia since aging can lead to loss of elasticity and a decrease in lung function. In addition, decrease in the immune response and comorbid conditions may also have impacts on the prognosis of pneumonia. People with decrease in organ function and immune responses accompanied with aging are more prone to have infection [22]. Mean hospital LOS of each group was about 7 days. In general, patients infected by a bacterium require hospitalization for about 7 to 10 days. Yet, it depends on the concomitant diseases, the development of complications, and the clinical severity of the disease [23]. The study found that most (69.70\%) of the patients in group without intervention received monotherapy, while, in the intervention group, less than half $(40.48 \%)$ of the patients received monotherapy. The need for combination therapy largely depends the disease severity [24].

With regards to antibiotics utilization, the patients in both groups were provided a wide range of antibiotics depends on their clinical states, results of the previous 6-month CST, and the available procured antibiotics. Initially, antibiotics were empirically provided to the patients concurrently with collection of sputum required to undertake CST. Empirical therapy is usually withheld until CST results are obtained. If there is an improvement in the clinical condition of the patients, the empirical therapy will be usually continued for 7 to 14 days, but it based on the clinical severity of the disease. If there is no improvement, then replacement of the antibiotics is done according to CST.

Patterns of antibiotic utilization were associated with the infecting pathogens, severity of the infections, medical conditions of the patients mainly kidney functions, pattern of the antibiotic resistance, body weight, age, medication history of the patients, and costs [25], [26]. Ceftriaxone was the most widely provided to the pneumonia patients in both groups. The frequent provision of ceftriaxone in both groups was probably because it is the most active cephalosporin against strains resistant to penicillin pneumococcus. In addition, it has longer half-life compared to those of other cephalosporins groups. Thus, it can be given 1 to 2 times with dose of 1 to $2 \mathrm{~g}$ daily. This long dosing interval could also improve the patients' compliance to their treatment [27].

The continuous antibiotic resistance remains a serious worldwide public health issue. Antibiotic resistance leads to increase morbidity, the patients' frequency of admission and their LOS as well as treatment costs and even mortality [28]. Inappropriate use of antibiotics in the treatment of pneumonia accelerates antibiotic resistance. The main drivers of the resistance are too short or too long a period of provision, too low or too high dose as well as under-use and over-use of antibiotics. These conditions causing antibiotics to treat pneumonia become less effective. Thus, efforts to fight antibiotic resistance and to improve their use in the treatment of many infections, including pneumonia, are continuously being done all over the world [29].

The main findings of this present study were few problems associated with the inappropriate use of antibiotics. These included problems related to the selection of too high doses of antibiotics provided to six and five patients with CKD in groups with and without interventions, respectively. These medical conditions are important to consider in determining dose of antibiotics to avoid from drug toxicity and fight antibiotics resistance [30]. Other problems were related to the length of treatments in which few antibiotics only need shorter and others required longer durations. These medical conditions required adjustment in the selection of dose and frequency of administration. Few cases were found where patients discharged from the hospital with continue taking the prescribed empirical therapy before CSTs were completed and interpreted. Of course, in the future treatment all these findings should be avoided to prevent and control the spread of antibiotic resistance [28], [31]. Other inappropriate uses of antibiotics were six and five effectivity problems in group with and without interventions, respectively. Other six cases were related to costs found only in group without intervention. The most important finding of this present study is that pharmacy intervention reduced significantly the incidence of inappropriate use of antibiotics in the treatment of patients with pneumonia. Incidence of inappropriate use of antibiotics per patient in group with the intervention was only $0.33(50 \%)$ of those in group without intervention. Thus, it is clear that active role of pharmacists should be highlighted and increased locally, regionally, and globally to reduce the incidence of inappropriate use of antibiotics which can further improve outcomes in the treatment of patients with pneumonia and minimize antibiotics resistance. The instrument developed by Gyssens is useful to assess and to study the accuracy of the antibiotics provision. This instrument has been widely used to evaluate the appropriate use of antibiotics to treat a wide range of infections in many countries [19].

Several similar studies on the appropriateness of antibiotics use for the treatment of pneumonia have been done by other researchers elsewhere. These studies indicated a wide range of appropriateness in antibiotic use for patients with pneumonia. A study was undertaken by Herawati in St. Vincentius $A$ Paulo hospital Surabaya Indonesia indicated that 
the appropriate provision of antibiotics to pneumonia patients was only $11.4 \%$ [32]. In 2019 , other study conducted by Ana Kusnul Faizah in a teaching hospital, Surabaya Indonesia found that $6 \%$ of the patients received less effective antibiotics, $6 \%$ of them were provided antibiotics with too long duration, the other $2 \%$ were provided inaccurate doses of antibiotics [33]. In addition, a retrospective study on rational use of antibiotics applying the Gyssens method indicated that only $51.1 \%$ of the 71 pneumonia patients included in the study were provided appropriate antibiotics [24]. This difference was thought to occur due to a wide range of complicated clinical conditions experienced by the patients and bacterial resistance to broad-spectrum antibiotics due to uncontrolled use of them as well as limited knowledge of the patients on the appropriate use of antibiotics [34]. A prospective multicenter observational study focused on the provision of $400 \mathrm{mg}$ moxifloxacin daily to 2733 patients with CAP for 10 days proved that $93.2 \%$ of the patients were cured [35].

Appropriate use of antibiotics can be achieved if all health care providers, including physicians, pharmacists, nurses, and other related health professionals work together as a team supported by policymakers. Physicians must be aware of the common infecting pathogens in the provision of empiric therapy for pneumonia. In addition, they must always prescribe the appropriate antibiotics to the right patients at the appropriate dose and frequency for the right length of provision and reduce unnecessary antibiotic use based on clinical practice guidelines, patient clinical conditions, and the most recent local bacterial resistance pattern [28], [36]. Pharmacists should also enhance their roles in implementing pharmaceutical care to identify and resolve the inappropriate use of antibiotics which can further reduce global antimicrobial resistance [33], [34].

This study was limited by the relatively small sample size and pharmacy intervention session related to the study timeline determined by the funding group. This study was only a single-center research. In this regard, the results and conclusions should be interpreted with caution. In the future, multi-center studies using more sample are required to support this study.

\section{Conclusions}

This study found that pharmacy intervention reduced significantly the inappropriate use of antibiotics in the treatment of patients with pneumonia. In the future, healthcare policymakers should consider the results of this study to enhance the roles of pharmacists and increase the appropriateness of management of pneumonia patients and combat the antibiotic resistance.

\section{Acknowledgments}

We would like to thanks to the Director of USU hospital, Medan, Indonesia for the endorsement provided in implementing this study. We also like to thanks to our student, Sri Aryanda, for the assistant provided.

\section{References}

1. Ruuskanen O, Lahti E, Jennings LC, Murdoch DR. Vira pneumonia. Lancet. 2011;377(9773):1264-75. https://doi. org/10.1016/s0140-6736(10)61459-6

PMid:21435708

2. World Health Organization. The Top Ten Causes of Death Geneva: World Health Organization; 2019. Available from: https://www.who.int/news-room/fact-sheets/detail/the-top-10causes-of-death. [Last accessed on 2019 Nov 30].

3. Ministry of Health, Agency of Health Research and Development. Main Results of RISKESDAS 2018. Jakarta: Balitbangkes Ministry of Health; 2018.

4. Prasso JE, Deng JC. Postviral complications: Bacterial pneumonia. Clin Chest Med. 2017;38(1):127-38. https://doi. org/10.1016/j.ccm.2016.11.006 PMid:28159155

5. Radovanovic D, Sotgiu G, Jankovic M, Mahesh PA, Marcos PJ, Abdalla MI, et al. An international perspective on hospitalized patients with viral community-acquired pneumonia. Eur J Intern Med. 2019;60:54-70.

PMid:30401576

6. Korsun N, Angelova S, Trifonova I, Georgieva I, Voleva S, Tzotcheva I, et al. Viral pathogens associated with acute lower respiratory tract infections in children younger than 5 years of age in Bulgaria. Braz J Microbiol. 2019;50(1):117-25. https:// doi.org/10.1007/s42770-018-0033-2

PMid:30637646

7. Dimov GS, Karakolev ZT, Kalchev IY, Dobrev KD. Ventilatorassociated pneumonia in patients with cerebral depression. Folia Med (Plovdiv). 2009;51(1):56-60.

PMid:19437899

8. Medscape References. Community-Acquired Pneumonia (CAP) Clinical Practice Guidelines; 2019. Available from: https://www. reference.medscape.com/viewarticle/920604. [Last accessed on 2021 May 12].

9. Moreira MR, Guimarães MP, Rodrigues AA, Gontijo Filho PP. Antimicrobial use, incidence, etiology and resistance patterns in bacteria causing ventilator-associated pneumonia in a clinical-surgical intensive care unit. Rev Soc Bras Med Trop. 2013;46(1):39-44. https://doi. org/10.1590/0037-868216722013

PMid:23563823

10. Okada N, Fushitani S, Azuma M, Nakamura S, Nakamura T, Teraoka K, et al. Clinical evaluation of pharmacist interventions in patients treated with anti-methicillin-resistant Staphylococcus aureus agents in a hematological ward. Biol Pharm Bull. 2016;39(2):295-300. https://doi.org/10.1248/bpb.b15-00774 PMid:26830489

11. Restrepo MI, Reyes LF, Anzueto A. Complication of communityacquired pneumonia (including cardiac complications). In: 
Seminars in Respiratory and Critical Care Medicine. Vol. 37. New York, United States: Thieme Medical Publishers; 2016. p. 897-904. https://doi.org/10.1055/s-0036-1593754

12. Ernst FR, Grizzle AJ. Drug-related morbidity and mortality: Updating the cost-of-illness model. J Am Pharm Assoc (Wash). 2001;41(2):192-9. https://doi.org/10.1016/ s1086-5802(16)31229-3

PMid:11297331

13. Cole J, Stark JE, Hodge B. A primary hospital antimicrobial stewardship intervention on pneumonia treatment duration. Fed Pract. 2017;34(2):14-8.

PMid:30766252

14. Dunaway S, Orwig KW, Arbogast ZQ, Myers ZL, Sizemore JA, Giancola SE. Evaluation of a pharmacy-driven methicillinresistant Staphylococcus aureus surveillance protocol in pneumonia. Int J Clin Pharm. 2018;40(3):526-32. https://doi. org/10.1007/s11096-018-0647-3 PMid:29721739

15. Subedi B, Louzon P, Zappas K, Onyia W, DeBoer K. Impact of pharmacist-led procalcitonin-guided antibiotic therapy in critically ill patients with pneumonia. Hosp Pharm. 2020;55(3):204-10. https://doi.org/10.1177/0018578719836643 PMid:32508359

16. Allerberger F, Amann S, Apfalter P, Brodt HR, Eckmanns T, Fellhauer $\mathrm{M}$, et al. Strategies to enhance rational use of antibiotics in hospital: A guideline by the German society for infectious diseases. Infection. 2016;44(3):395-439. https://doi. org/10.1007/s15010-016-0885-z

PMid:27066980

17. World Health Organization. Regional Office for the Western Pacific. Health Research Methodology: A Guide for Training in Research Methods. Geneva: World Health Organization; 2001.

18. Medscape. Bacteria Pneumonia Treatment and Management. Available from: https://www.emedicine.medscape.com/ article/300157-treatment\#d8. [Last accessed on 2021 May 12].

19. Gyssens IC. Audit for monitoring the quality of antimicrobial prescription. In: Gould IM, van der Meer WM, editors. Antibiotikas Policies: Theory and Practice. New York: Spinger; 2005. p. 197-226.

20. Kalil AC, Metersky ML, Klompas M, Muscedere, Sweeney DA, Palmer LB, et al. Management of adults with hospital-acquired and ventilator-associated pneumonia: 2016 clinical practice guidelines by the infectious diseases society of America and the American thoracic society. Clin Infect Dis. 2016;63(5):e61-111. https://doi.org/10.1093/cid/ciw353

PMid:27418577

21. Lim WS, Smith DL, Wise MP, Welham SA. British thoracic society community acquired pneumonia guideline and the NICE pneumonia guideline: How they fit together. BMJ Open Respir Res. 2015;2(1):e000091. https://doi.org/10.1136/ bmjresp-2015-000091 PMid:26019876

22. Henig O, Kaye KS. Bacterial pneumonia in older adults. Infect Dis Clin. 2017;31(4):689-713.

PMid:28916385

23. Kothe H, Bauer T, Marre R, Suttorp N, Welte T, Dalhoff $\mathrm{K}$, et al. Outcome of community-acquired pneumonia: Influence of age, residence status and antimicrobial treatment. Eur Resp J.
2008;32(1):139-46. https://doi.org/10.1183/09031936.00092507 PMid:18287129

24. Menéndez R, Torres A, de Castro FR, Zalacaín R, Aspa J, Villasclaras $\mathrm{JJ}$, et al. Reaching stability in community-acquired pneumonia: The effects of the severity of disease, treatment, and the characteristics of patients. Clin Infect Dis. 2004;39(12):178390. https://doi.org/10.1086/426028

PMid: 15578400

25. What Antibiotics are Used to Treat Pneumonia? 2019. Available from: https://www.drugs.com/medical-answers/antibiotics-treatpneumonia-3121707. [Last accessed on 2019 Dec 02].

26. Leekha S, Terrell CL, Edson RS. General principles of antimicrobial therapy. In: Mayo Clinic Proceedings 2011. Vol. 86. Amsterdam, Netherlands: Elsevier; 2011. p. 156-67. https://doi. org/10.4065/mcp.2010.0639

27. DailyMed. Ceftriaxone: Dosage and Administration. Available from: https://www.dailymed.nlm.nih.gov/dailymed/druglnfo. cfm?setid=9bcf7973-54fa-487c-99da-db8a92b5e074. [Last accessed on 2021 May 12].

28. Leung E, Weil DE, Raviglione M, Nakatani $\mathrm{H}$. The WHO policy package to combat antimicrobial resistance. Bull World Health Organ. 2011;89(5):390-2. https://doi.org/10.2471/blt.11.088435 PMid:21556308

29. Centers for Disease Control and Prevention. Antibiotic Prescribing and Use in Doctor's Offices. Continuing Education and Informal Resources; 2020. Available from: https://www.cdc. gov/antibiotic-use/community/index.html. [Last accessed on 2020 Sep 19].

30. Azizah N, Azhar SS, Ainnal SA. Evaluation of antibiotics utilization and dosing for management of patients with chronic kidney disease in an Indonesian hospital. Asian J Pharm Clin Res. 2015;8(1):29-302.

31. Pogue JM, Kaye KS, Cohen DA, Marchaim D. Appropriate antimicrobial therapy in the era of multidrug-resistant human pathogens. Clin Microbiol Infect. 2015;21(4):302-12. https://doi. org/10.1016/j.cmi.2014.12.025 PMid:25743999

32. Herawati R. Review of Antibiotic Utilization in St. Vincentius A Paulo Hospital, Surabaya. Indonesia: Universitas Surabaya; 2006.

33. Faizah AK, Putra ON. Qualitative evaluation of antibiotic therapy in patients with pneumonia at Surabaya Indonesia teaching hospital. JSFK J Pharm Sci Clin. 2019;6(2):129-33.

34. World Health Organization. Rational Use of Medicines, Fact Sheet No. 338. Geneva: World Health Organization; 2010. Available from: http://www.who.int/mediacentre/factsheets/ fs338/en. [Last accessed on 2017 Oct 22].

35. Kuzman I, Bezlepko A, Topuzovska IK, Rokusz L, ludina L, Marschall HP, et al. Efficacy and safety of moxifloxacin in community acquired pneumonia: A prospective, multicenter, observational study (CAPRIVI). BMC Pulm Med. 2014;14:105. https://doi.org/10.1186/1471-2466-14-105 PMid:24975809.

36. Zilberberg MD, Nathanson BH, Sulham K, Fan W, Shorr AF. Carbapenem resistance, inappropriate empiric treatment and outcomes among patients hospitalized with enterobacteriaceae urinary tract infection, pneumonia and sepsis. BMC Infect Dis. 2017;17(1):279. https://doi.org/10.1186/s12879-017-2383-z PMid:28415969 